\title{
Evaluation of passiflora edulis flavicarpa and dioscorea spp. peelings as potential raw material for biorefineries
}

The use of agro-industrial residues in biorefinery processes has been increasing due to the negative environmental impact associated with the excessive use of fossil fuels. Several residues have been evaluated as precursors for carbohydrate production, which in turn can be converted into numerous high value-added products, such as the products of the furanic series, 5-hydroxymethylfurfural and furfural. Thus, this work aimed to determine the chemical composition of passion fruit and purple yam peels in order to analyze their potential for use as raw material for biorefineries. For the determination of sugars, the shells were submitted to acid hydrolysis according to two different methodologies: one by the National Renewable Energy Laboratory method and the other by the Dunnin et al. (1949) methodology. The products obtained were analyzed by Fourier Transform Infrared Spectrophotometry and High-Performance Liquid Chromatography. The results show that passion fruit and purple yam peels presented high percentages of hemicellulose ( $30 \%$ and $15 \%$, respectively) and mainly of cellulose (above $44 \%$ for both shells according to the two tested methodologies). Due to the significant amount of these polysaccharides present in the biomass, they have potential for use in biorefineries.

Keywords: Biorefinery; Agroindustrial Waste; Hydrolysis; Hemicellulose; Cellulose.

\section{Avaliação de passiflora edulis flavicarpa e dioscorea spp. cascas como matéria-prima potencial para biorrefinarias}

\begin{abstract}
O uso de resíduos agroindustriais em processos de biorrefino tem aumentado devido ao impacto ambiental negativo associado ao uso excessivo de combustíveis fósseis. Vários resíduos foram avaliados como precursores para a produção de carboidratos, que por sua vez podem ser convertidos em inúmeros produtos de alto valor agregado, como as séries 5-hidroximetilfurfural e furfural. Assim, este trabalho teve como objetivo determinar a composição química de cascas de maracujá e inhame roxo, a fim de analisar seu potencial de utilização como matéria-prima para biorrefinarias. Para a determinação dos açúcares, as cascas foram submetidas à hidrólise ácida de acordo com duas metodologias distintas: uma pelo método do National Renewable Energy Laboratory e outra pela metodologia de Dunning et al. (1949). Os produtos obtidos foram analisados por Espectrofotometria de Infravermelho com Transformada de Fourier e Cromatografia Líquida de Alta Eficiência. Os resultados mostram que as cascas de maracujá e inhame roxo apresentaram elevados percentuais de hemicelulose (30\% e 15\%, respectivamente) e principalmente de celulose (acima de $44 \%$ para ambas as cascas pelas duas metodologias testadas). Devido à quantidade significativa desses polissacarídeos presentes na biomassa, eles têm potencial para uso em biorrefinarias.
\end{abstract}

Palavras-chave: Biorrefinaria; Resíduos Agroindustriais; Hidrólise; Hemicelulose; Celulose.

Mariana de Souza Borges (iD Universidade Federal do Tocantins, Brasil http://lattes.cnpq.br/6881575136491408 http://orcid.org/0000-0003-2311-883X mariana.borgess@mail.uft.edu.br

\section{Jéssyka Ribeiro Santos (it}

Universidade Federal do Tocantins, Brasil http://lattes.cnpq.br/3207507715174801 http://orcid.org/0000-0002-8961-4724 jessyka.rib27@gmail.com

\section{Magale Karine Diel Rambo (10)}

Universidade Federal do Tocantins, Brasil http://lattes.cnpq.br/8793967773394967 http://orcid.org/0000-0003-2529-9574 magalerambo@uft.edu.br
Donizete Xavier da Silva

Universidade Federal de São Carlos, Brasil http://lattes.cnpq.br/2979057145871809 donizete@mail.uft.edu.br

\section{Nicole Marasca}

Universidade Federal do Tocantins, Brasil http://lattes.cnpq.br/6024283678671808 nicolemarasca@gmail.com

\section{Michele Cristiane Diel Rambo (id}

Instituto Federal de Educação, Ciência e Tecnologia do Tocantins, Brasil

http://lattes.cnpq.br/9995461414291019

http://orcid.org/0000-0002-5329-4933

michele.rambo@ifto.edu.br
Elisandra Scapin (iD

Universidade Federal do Tocantins, Brasil http://lattes.cnpq.br/9765872633375212 http://orcid.org/0000-0001-7506-308X elisandrascapin2015@gmail.com
Referencing this:

BORGES, M. S.; SANTOS, J. R.; RAMBO, M. K. D.; SILVA, D. X.; MARASCA, N.; RAMBO, M. C. D.; SCAPIN, E.. Evaluation of passiflora edulis flavicarpa and dioscorea spp. peelings as potential raw material for biorefineries. Revista Ibero Americana de Ciências Ambientais, v.12, n.5, p.504-514, 2021. DOI: http://doi.org/10.6008/CBPC21796858.2021 .005 .0040 


\section{INTRODUCTION}

Due to the continuous and growing demand for energy and the impacts on climate change, the chemical industry is in a transition scenario from dependence on non-renewable raw materials such as crude oil or natural gas to vegetable biomass. Thus, the identification and use of alternative energy sources has become a major strategic challenge for the $21^{\text {st }}$ century (PEREZ et al., 2019; ALAM et al., 2018; VAZ JÚNIOR., 2017). According to Vaz Júnior (2017), Brazil has an agro-industrial production that stands out in the world scenario, producing approximately 330 million/tons annually of agro-industrial waste. This scenario characterizes a favorable environment for the advancement of sustainable chemistry, with a large contribution from biomass waste as a renewable source. Within this context, the technologies that make up the processes of biorefineries, used in the exploitation of waste, become increasingly important (RAMBO, 2011).

Considering this scenario, lignocellulosic biomass has emerged as one of the most promising alternatives to fossil fuels for being a renewable, low-cost and easily accessible raw material, avoiding competition with food sources and arable land. This can vary in composition depending on the type of biomass, location, climate conditions and characteristics of the soil in which it grows (ASIM et al., 2019; LI et al., 2019). Lignocellulosic biomass is composed of biopolymers, including cellulose (40-60\%), hemicellulose (20-40\%), and lignin (10-24\%) (SINGH et al., 2017). Generally, the acidic degradation or hydrolysis of the constituents of this biopolymer, i.e., cellulose and hemicellulose, results in the formation of hexose and pentose sugars (DAORATTANACHAl et al., 2013). The application of these derived sugars is, in turn, very present within the concept of "integrated biorefineries", mainly their conversion into biofuels such as bioethanol, and high added value biopolymers (BRANDT et al., 2013).

To optimize the use of raw biomass in biorefinery processes, it is essential to know and understand the physical aspects, as well as the chemical properties of biomass and its characteristics (RAMBO et al., 2015). Another crucial aspect is the choice of the most appropriate methodology or process for the release of carbohydrates present in each biomass, given that the decomposition of the polymers into their constituent monomer before conversion into value-added chemicals is a key step in this process, as each of the polymers has different degrees of recalcitrance for fractionation methods and different potential end products (AJAO et al., 2018).

Therefore, this study selected passion fruit peels (Passiflora edulis flavicarpa) and purple yam (Dioscorea spp.) for chemical and physical characterization, with the objective of evaluating their potential for use in biorefining processes. Considering that Brazil is the first worldwide producer of passion fruit with production in 2017 of $13.50 \mathrm{t} / \mathrm{ha}$, the passion fruit peel corresponds to $52 \%$ of the fruit's composition (EMBRAPA, 2017). Purple yam is a staple food that portrays great importance in traditional Brazilian agriculture, composed mainly of starch. In this context, these residues have characteristics and functional properties that can be used for the development of a good sustainable biomaterial in the industrial production of furan compounds and can also be used in biorefineries.

The choice of passion fruit peel and purple yam peel as a source of biomass was motivated by the 
fact that they are commonly unused, cheap and renewable residues and that contain mainly carbohydrate in their composition, and may be beneficial for the economical production on a commercial scale furanic compounds.

\section{METHODOLOGY}

The passion fruit (Passiflora edulis flavicarpa) and purple yam (Dioscorea spp.) peelings were acquired in regional supermarkets in Palmas - TO, Brazil. The analyses were performed at the Chemistry Laboratory of the Federal University of Tocantins - UFT. The biomass of the passion fruit peel was obtained from the mesocarp (interior of the peel) and epicarp (peel) of the passion fruit and the biomass of the purple yam only from the peel. The biomasses were then cleaned and dried at room temperature for 48 hours, and for another 12 hours in a drying oven at $105{ }^{\circ} \mathrm{C}$ (SSD SolidSteel 110L). In the physical pretreatment, the peels were individually milled (22 mesh) (Start FT 50 - Fortinox), sieved to particle size (180$850 \mu \mathrm{m})$ and stored in airtight glass bottles for later use.

A total of $10 \mathrm{~mL}$ of $72 \%$ sulfuric acid $\left(\mathrm{H}_{2} \mathrm{SO}_{4}\right)$ was added to two grams of each biomass. The mixture was stirred continuously with a glass rod for 7 minutes in a water bath (Fisatom, 550, Brazil) at $50{ }^{\circ} \mathrm{C}$. Then, $40 \mathrm{~mL}$ of distilled water was added to this content and the material was transferred to a $250 \mathrm{~mL}$ Erlenmeyer flask. The solution was taken to the autoclave (vertical, Phoenix brand) at $121{ }^{\circ} \mathrm{C}$ for 15 minutes. After cooling, the material was filtered on filter paper previously weighed, to separate the solid and liquid fractions. The liquid fraction of the hydrolysate was used to evaluate the carbohydrate contents (glucose and fructose) and soluble acid lignin. The solid fraction retained in the filter paper was used to analyze the contents of insoluble acid lignin and insoluble acid residue.

Approximately $300 \mathrm{mg}$ of each biomass were subjected to a two-stage acid hydrolysis process. In the first stage, the $72 \%(3 \mathrm{~mL}$ ) sulfuric acid sample was transferred to a water bath (Fisatom, 550, Brazil), kept at $30{ }^{\circ} \mathrm{C}$ for 1 hour and agitated every 10 minutes. In the second stage, $84 \mathrm{~mL}$ of water was added to the sample and it was transferred to the autoclave (vertical, Phoenix brand) for 1 hour at $120^{\circ} \mathrm{C}$. The hydrolyzed samples were then filtered through medium porosity crucibles (10 to $15 \mu \mathrm{m})$ using a vacuum pump (LT 65, Limatec, coupled). The liquid fraction of the hydrolysate was used to assess the carbohydrate and soluble acid lignin content. The solid fraction was used to analyze insoluble acid lignin and insoluble acid ash content of the sample. The content of soluble acid lignin was determined using the hydrolysate diluted in $\mathrm{H}_{2} \mathrm{SO}_{4}$ solution at $4 \%$ in UV-Vis spectrophotometer ( $\mathrm{HACH} /$ Germany, DR5000) with wavelength of $294 \mathrm{~nm}$.

For determining the insoluble acid lignin content by the method adapted from Rocha et al. (2015), the liquid fraction of hydrolysate obtained through the methodology of Dunning et al. (1949) was washed with distilled water, aiming to remove sulfuric acid. The paper was then dried in an oven (SolidSteel) at 60 ${ }^{\circ} \mathrm{C}$ until constant mass was reached. Total lignin was defined by the sum of insoluble acid lignin and soluble acid lignin found after the acid hydrolysis procedure.

The insoluble acid residue resulting from the filtration of the hydrolysate obtained by the NREL 
methodology, was used to determine the insoluble acid lignin. The insoluble acid residue was washed with distilled water until the complete removal of the acid, and then dried in an oven at $105 \pm 5{ }^{\circ} \mathrm{C}$ until a constant mass. It was then taken to the muffle furnace at $575{ }^{\circ} \mathrm{C}$ for determination of the insoluble acid ash. Insoluble acid lignin was determined by the difference between insoluble acid residue and insoluble acid ash. The ash content of biomass was determined according to ASTM D3174-04 (American Society for Testing, 2004) which consists of the analysis of the residue after combustion of $1 \mathrm{~g}$ of crude biomass in a muffle furnace at $600{ }^{\circ} \mathrm{C}$ for four hours.

The determination of the extractive content was performed in a Soxhlet extractor, using $3 \mathrm{~g}$ of sample from each biomass, placed in extraction cartridges, covered with cotton and then taken to the extractor with $200 \mathrm{~mL}$ of ethanol (95\%), for approximately 12 hours (RAMBO et al., 2015). After the end of the reflux, the cartridges were placed in Petri dishes on the counter for 48 hours for drying, and then the extractive content was calculated. The determination of hemicellulose and cellulose content present in the samples was performed according to Acid Detergent Fiber and Neutral Detergent Fiber analysis (TRUJILLO et al., 2010).

HPLC analysis was performed for carbohydrate determination hydrolyzed samples. For this, the Shimadzu chromatograph was used, employing Phenomenex Rezex ROA-Organic column acid $\mathrm{H}^{+}(81 \%)$, and using $\mathrm{H}_{2} \mathrm{SO}_{4}$ acid $\left(5 \mathrm{mM}\right.$ ) as eluent, with flow rate of $0.6 \mathrm{~mL} \mathrm{~min}^{-1}$ and refractive index detector model SPD10A VP brand Shimadzu. The volume of the injected sample was $20 \mu \mathrm{L}$. The samples were previously diluted and filtered in "Sep-Pack" C18 (Millipore). The concentrations of these compounds were calculated from calibration curves obtained from standard solutions.

The determination of hydroxymethylfurfural and furfural was performed using Phenomenex Luna C18 5 column $\mu$ (2) $(250 \times 4.6 \mathrm{~mm})$ and pre-column Phenomenex C18 $(4 \times 3.0 \mathrm{~mm})$ filled with material similar to the main column. The eluent flow is $1 \mathrm{~mL} / \mathrm{min}$, at $30{ }^{\circ} \mathrm{C}$, with a total run time of 15 minutes. The isocratic elution with an acetonitrile/water solution (1:8 with $1 \%$ acetic acid), the detector used was the UV (SPD-10A) with wavelength at $276 \mathrm{~nm}$. The concentrations of these compounds were calculated from calibration curves obtained from standard solutions.

In order to verify the presence of carbohydrates and furanic compounds in the biomass hydrolysates, the samples were submitted to infrared analysis in an infrared spectrophotometer with Fourier transform (FTIR) CARY 630, from Agilent Technologies with a scanning range of 600 to $3500 \mathrm{~cm}^{-1}$.

The effect of the methodologies on the chemical composition of the biomass was investigated through a factorial planning. It is an experimental method that allows the analysis of the effect of two or more variables (factors) that influence the responses simultaneously. A factorial planning requires the execution of experiments for all possible combinations of factor levels. In case there are $k$ factors, that is, $k$ variables investigated, the planning of two levels will require the realization of different tests, thus being called factorial planning $2^{k}$ (NETO et al., 2007). In this work, a $2 \times 2$ factorial was employed involving, therefore, four experiments. 


\section{RESULTS AND DISCUSSION}

Table 1 presents the chemical composition according the two different methodologies. In general, it is noticeable that the lower lignin content of biomass, greater the bioavailability of the substrate for generation bioproducts and bioethanol (PU et al., 2013). According to Singh et al. (2017), lignocellulosic biomasses are composed on average of 10 to $24 \%$ lignin.

Table 1: Chemical composition of passion fruit and purple yam (dry base).

\begin{tabular}{|l|l|l|l|}
\hline \multicolumn{1}{|c|}{ Components } & Methodology & Passion Fruit Peel & Purple Yam Bark \\
\hline \multirow{2}{*}{ Insoluble acid lignin (\%) } & Rocha et al. (2015) & $10.53 \pm 1.09$ & $10.43 \pm 2.89$ \\
\cline { 2 - 4 } & NREL & $2.30 \pm 0.04$ & $1.16 \pm 0.04$ \\
\hline \multirow{2}{*}{ Soluble acid lignin (\%) } & Rocha et al. (2015) & $14.23 \pm 0.89$ & $33.02 \pm 0.36$ \\
\cline { 2 - 4 } & NREL & $25.95 \pm 3.53$ & $4.19 \pm 0.01$ \\
\hline \multirow{2}{*}{ Total lignin (\%) } & Rocha et al. (2015) & 24.76 & 43.45 \\
\cline { 2 - 4 } & NREL & 28.25 & 5.35 \\
\hline \multirow{2}{*}{ Cellulose (\%) } & Rocha et al. (2015) & 55.74 & 51.44 \\
\cline { 2 - 4 } & \multicolumn{1}{|c}{ NREL } & 44.02 & 80.27 \\
\hline Hemicellulose (\%) & 30.03 & 15.54 \\
\hline Ashes (\%) & $10.33 \pm 0.07$ & $12.56 \pm 0.23$ \\
\hline Extractive (\%) & $11.54 \pm 0.18$ & $3.73 \pm 0.94$ \\
\hline
\end{tabular}

Mean \pm Standard-Deviation (averages of three repetitions)

In this study the passion fruit peel presented total lignin levels of $24.76 \%$ and $28.25 \%$, according Rocha et al. (2015) and NREL (2011) methods, respectively. Silva (2015) determined $25.69 \%$ of total lignin for this same biomass. Hiep et al. (2020), obtained $10.7 \%$ of lignin content of passion fruit bagasse. This high lignin content can be explained because the bagasse is not only composed of bark, but also of other types of lignocellulosic materials.

The bark of purple yam presented $43.45 \%$ of total lignin according to Rocha et al. (2015) and only 5.35\% according to NREL (2011). These values are quite discrepant between themselves, which highlights the importance of the correct choice of methodology according to the purpose of each process and types of biomass. No reference values for total lignin of bark of purple yam were found in the literature; however, Versino et al. (2015) had lignin content values of $23.59 \%$ of cassava peel.

Both biomasses presented close levels of ash content, $10.33 \%( \pm 0.07)$ and $12.56 \%( \pm 0.23)$, respectively (Table 1). According to Macedo et al. (2016), in order to be used in biorefinery processes, the biomass must present low ash values. When comparing the ash content of passion fruit peel with other biomasses, coconut peel presents 3.63\% (RAMBO et al., 2015) and orange peel, 33.0\% (CHAU et al., 2003). The samples of the purple yam peels analyzed presented ash contents higher than Martins et al. (2014), who evaluated the ashes for the pulp of the cará-do-ar (Dioscorea bulbifera L.) and obtained $0.90 \%$. This value can be explained because, according to Leite (2016), the peel has more fibers than the pulp. Consequently, the ash content of the peel will be higher than that of the pulp. Other factors that influence the results are the differences of species, planting regions and genetic conditions of the plant, among others.

The low percentage of extractives is essential when it comes to reducing production costs, and economically and environmentally favorable, because the higher the content of extractives, the higher the 
consumption of solvents and waste generation. In addition, extractives can interfere with acid hydrolysis (RAMBO et al., 2015). It is possible to observe that passion fruit peel has a higher content of extractives than the purple yam peel (11.54 and 3.73, respectively); therefore, the purple yam bark is the biomass that best fits this requirement, and the low values of extractives found in this study do not indicate the need for removal (BROWNING, 1967).

Regarding the hemicellulose content, the results obtained allowed verifying that the passion fruit peel obtained higher values. With respect to cellulose, the purple yam peel presented a higher result than passion fruit peel according to NREL; however, the reverse occurs using methodology of Rocha et al. (2015).

Silva (2014) determined $12.98 \%$ of hemicellulose and $40.35 \%$ of cellulose for the passion fruit peel; nonetheless, the hemicellulose content is lower than what was found in this study using both methodologies, an attractive fact when it comes to obtaining carbohydrates. Leite (2016) analyzed the composition of cassava peel and presented $14.8 \%$ of cellulose, a value inferior to what was presented for the purple yam peel in this study for both methodologies. The great variation observed in the percentages can be explained by the variability of the species.

In this sense, hydrolysis according to Dunning et al. (1949) resulted in higher yields for hemicellulose (30.03\% for passion fruit peel); nevertheless, for cellulose the highest percentages obtained were in accordance with NREL hydrolysis (2011) $(80.27 \%$ for the bark of purple yam); this value, however, is far from other studies such as those mentioned above. In Figure 1, the spectra of the hydrolyzed samples of bark of purple yam and passion fruit peel are found, respectively, according to methodology developed by Dunning et al. (1949) (I) and methodology developed by NREL (2011) (II).

The analysis of the absorption spectrum in the infrared region revealed the presence of bands typical of the characteristic functional groups of lignocellulosic materials. In Figure 1, for bark of purple yam (A) a rounded and broad-based peak is observed in the region of $3333.569 \mathrm{~cm}^{-1}$ (II) and $3263.509 \mathrm{~cm}^{-1}$ (I), and for passion fruit peel (B) in the region of $3333.174 \mathrm{~cm}^{-1}$ (II) and $3265.435 \mathrm{~cm}^{-1}$ (I), which, as described by Zhao et al. (2010), correspond to the axial deformation of the chemically associated hydroxyl groups (-OH). Tibolla et al. (2014) states that after analysis of pulp, hemicellulose and lignin, the highest absorption of groups $-\mathrm{OH}$ was obtained for pulp. This confirms that there has been cellulose degradation, or at least severe modifications in its structure. The peaks in the region $1636.515 \mathrm{~cm}^{-1}(A-1)$ and in the region 1636.800 $\mathrm{cm}^{-1}(\mathrm{~A}-\mathrm{II})$, and in the region $1636.762 \mathrm{~cm}^{-1}(\mathrm{~B}-\mathrm{I})$ and $1636.835 \mathrm{~cm}^{-1}$ (B-II), according to Siqueira et al. (2010), are attributed to the deformation of $\mathrm{C}=\mathrm{O}$ groups of xylangroups, the main component of hemicellulose and also of lignin chemical groups, as well as it is present in the furanic compounds hydroxymethylfurfural and furfural. It is still possible to observe the absorption bands in the region of 1200 to $932 \mathrm{~cm}^{-1}$, characteristics of the $\mathrm{C}-\mathrm{O}$ and $\mathrm{C}-\mathrm{H}$ vibrations of pulp, confirming the efficiency of acid hydrolysis on the pulp structure. 

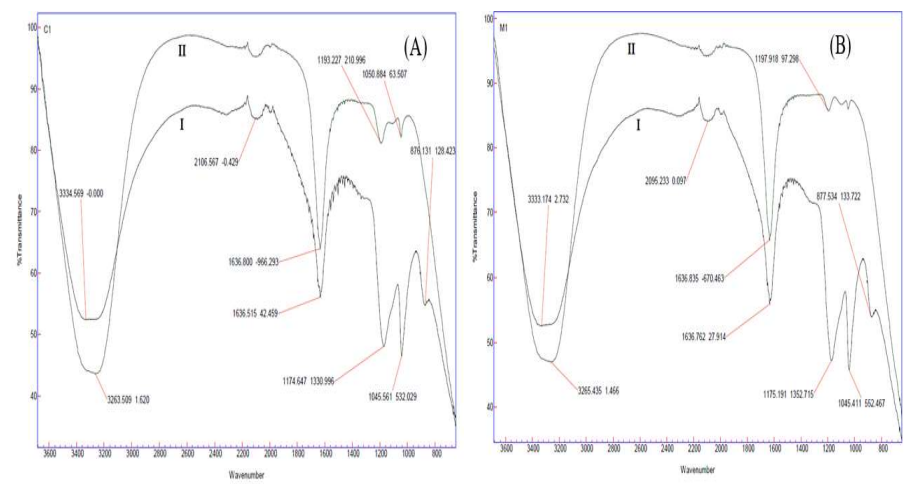

Figure 1: FTIR spectra of the hydrolysate of Purple Yam Peel in (A) of Passion Fruit Peel in (B), according to a methodology developed by (I) DUNNING et al. (1949) and (II) NREL (2011).

The spectra of the hydrolyzed samples developed according to the methodology of Dunning et al. (1949) showed significant structural degradation in relation to the hydrolyzed samples developed according to the NREL methodology, demonstrating that the former is able to degrade more efficiently structural components of lignocellulosic biomass. Table 2 presents the values obtained by quantifying the glucose and fructose levels and hydroxymethylfurfural and furfural, present in the samples of passion fruit peel and purple yam peel.

Table 2: Quantification of carbohydrates and furanic compounds (dry basis).

\begin{tabular}{|c|l|c|c|}
\hline Components & \multicolumn{1}{|c|}{ Methodology } & Passion Fruit Peel & Purple Yam Bark \\
\hline \multirow{2}{*}{ Glucose (\%) } & Dunning et al. (1949) & $0.544 \pm 0.157$ & $0.893 \pm 0.057$ \\
\cline { 2 - 4 } & NREL & $0.061 \pm 0.014$ & $0.07 \pm 0.006$ \\
\hline \multirow{2}{*}{ Fructose (\%) } & Dunning et al. (1949) & $0.133 \pm 0.002$ & $0.269 \pm 0.018$ \\
\cline { 2 - 4 } & NREL & $0.029 \pm 0.006$ & $0.019 \pm 0.005$ \\
\hline \multirow{2}{*}{ Hydroxymethylfurfural (\%) } & Dunning et al. (1949) & $0.004 \pm 0.0$ & $0.008 \pm 0.002$ \\
\cline { 2 - 4 } & NREL & $0.006 \pm 0.0$ & $0.001 \pm 0.001$ \\
\hline \multirow{2}{*}{ Furfural (\%) } & Dunning et al. (1949) & $0.125 \pm 0.002$ & $0.096 \pm 0.004$ \\
\cline { 2 - 4 } & NREL & $0.002 \pm 0.0$ & $0.002 \pm 0.0$ \\
\hline
\end{tabular}

Mean \pm Standard-Deviation (averages of three repetitions)

Based on the results obtained, it can be verified that bark of purple yam presented higher levels of glucose than the passion fruit rind, according to the two methodologies. This fact can be explained by the high levels of cellulose, a biopolymer that degrades into glucose monomers, found in this biomass. In relation to the percentage of fructose, the purple yam bark presented higher values according to Dunning et al. (1949), but the inverse occurs according to NREL. Fructose is one of the pentoses constituents of hemicellulose; therefore, it is causally linked to the concentration of this polymer. In this sense, the passion fruit peel was the one that presented the highest levels of hemicellulose, and consequently, according to NREL, the hydrolysis was the one that demonstrated the greatest efficiency in the structural degradation of hemicellulose in fructose for this biomass.

Regarding the levels of furanic compounds, found after hydrolysis, it can be seen that the purple yam bark presented higher values of hydroxymethylfurfural according to Dunning et al. (1949) (0.008\%); however, according to NREL hydrolysis (2011), the passion fruit peel presented better results $(0.006 \%)$. It should also be noted that the concentration of hydroxymethylfurfural presented was excessively low for both biomasses and methodologies. Passion fruit peel was the biomass with the highest furfural content, 
according to Dunning et al. (1949). Nevertheless, according to the NREL methodology, both biomasses presented equal values (0.002\%) and lower than the quantity obtained by Dunning et al. (1949).

In general, it was verified that the methodology of Dunning et al. (1949) was the one that provided higher levels of glucose, fructose, hydroxymethylfurfural and furfural; and through this same methodology, the purple yam peel has exceeded the passion fruit peel in the amount of glucose, fructose and hydroxymethylfurfural. Consequently, Dunning et al. (1949) are more suitable to be used for this biomass than NREL. This behavior was similar to that observed by Borges et al. (2020) who obtained yields of up to $14.28 \%$ glucose in rice husk hydrolysis, according to Dunning et al. (1949), against only $1.67 \%$ glucose yields obtained by NREL.

The results also indicate that both biomasses presented low levels of glucose, fructose, hydroxymethylfurfural and furfural. The insignificant sugar levels demonstrate that the choice of both methodologies may not be ideal for the efficient degradation process of the natural cellulose and hemicellulose polymers that form these biomasses, which were detected in high amounts in both. In Table 2 , the purple yam peel is the biomass preferred for the use of these biomasses as a source of glucose, since it presents more glucose than the passion fruit peel, according to the two methodologies tested.

The purple yam rind presented higher fructose contents than the passion fruit rind, according to the hydrolysis methodology performed by Dunning et al. (1949). In the analysis of the hydrolysis performed by the NREL methodology, the passion fruit peel presented higher fructose contents than the purple yam peel. Therefore, for the use of these biomasses as a source of fructose in the production of fine chemical compounds, when analyzing the criterion of which biomass to use, the purple yam peel presented more fructose than the passion fruit peel by the hydrolysis methodology developed by Dunning et al. (1949). However, if analyzed which methodology generates better results, the hydrolysis methodology developed by Dunning et al. (1949) showed higher values compared to the hydrolysis developed by the NREL methodology.

The biomasses tested generated more furfural after acid hydrolysis than hydroxymethylfurfural, except for the passion fruit peel hydrolysis performed by the NREL methodology. The hydrolysate from the purple yam bark showed more hydroxymethylfurfural by Dunning et al. (1949) methodology compared to the passion fruit peel. Nevertheless, when the results of the hydrolysis performed by the NREL methodology were analyzed, the passion fruit peel generated higher hydroxymethylfurfural results than the purple yam peel. Comparing the two biomasses tested, the biomass that generated the most hydroxymethylfurfural after the acid hydrolysis was the purple yam bark, according to Dunning et al. (1949) methodology. If the hydrolysis methodology that obtained the best results for obtaining hydroxymethylfurfural is analyzed, the methodology developed by Dunning et al. (1949) obtained superior results to the methodology developed by NREL.

By analyzing the results obtained for furfural, the passion fruit peel resulted in a higher amount of furfural when compared to the purple yam peel, according to Dunning et al. (1949) hydrolysis methodology. The hydrolysate obtained by the NREL methodology presented similar furfural values for 
both biomasses. Therefore, the biomass that presented more furfural after hydrolysis, for both methodologies, was the passion fruit peel. And when analyzed the methodology that obtained better furfural results after acid hydrolysis, the methodology developed by Dunning et al. (1949) obtained better results than the methodology for hydrolysis developed by NREL in obtaining furfural.

The results of the analysis of the effect of the methodologies on the chemical composition of the studied biomasses are presented in Tables 3 and 4 and represent all the possible combinations of the planning variables and the estimates indicate the mean (estimate 1), the main effects of the studied variables (estimates 2 and 3 ), and the interaction effect between them (estimate 4).

In Table 3, the results of the carbohydrate content are presented, and in Table 4, the concentration of sugars and furanic compounds. In Table 3 , it is observed that when biomass $B_{1}$ (passion fruit peel) is used and the methodology changes from $M_{1}$ (NREL) to $M_{2}$ (ROCHA et al., 2015), the insoluble acid lignin content goes from 2.30 to 10.53 , a variation of 8.23 . Maintaining the biomass $B_{2}$ (purple yam bark) and varying the methodology from $M_{1}$ to $M_{2}$ (experiments 3 and 4) the insoluble acid lignin goes from 1.16 to 10.43 , variation of 9.27. This behavior indicates that $M_{2}$ was more efficient in the process of obtaining lignin and the two biomasses proved to have practically the same content of this carbohydrate. Also observing the estimates, it is noted that the main effect of the methodology is much more significant than biomass (estimates 2 and 3 ) and, in this case, the interaction effect is not significant (estimate 4).

Table 3: Estimates and effects of variables on the chemical composition of biomasses

\begin{tabular}{|c|c|c|c|c|c|c|c|c|}
\hline \multirow{3}{*}{ Components (\%) } & \multicolumn{4}{|c|}{ Experiments } & \multicolumn{4}{|c|}{ Estimates } \\
\hline & 1 & 2 & 3 & 4 & 1 & 2 & 3 & 4 \\
\hline & $\mathrm{M}_{1} \mathrm{~B}_{1}$ & $\mathrm{M}_{2} \mathrm{~B}_{1}$ & $M_{1} B_{2}$ & $\mathrm{M}_{2} \mathrm{~B}_{2}$ & Mean & MTD & BMS & MTD/BMS \\
\hline Insoluble acid lignin & 2.30 & 10.53 & 1.16 & 10.43 & 6.11 & 8.75 & -0.62 & 0.52 \\
\hline Soluble acid lignin & 25.95 & 14.23 & 4.19 & 33.02 & 19.35 & 8.56 & -1.49 & 20.28 \\
\hline Total Lignin & 28.25 & 24.76 & 5.35 & 43.45 & 25.45 & 17.31 & -2.11 & 20.80 \\
\hline Cellulose & 44.02 & 55.74 & 80.27 & 51.44 & 57.87 & -8.56 & 15.98 & -20.28 \\
\hline
\end{tabular}

$M_{1}=$ NREL; $M_{2}=$ Rocha et al. (2015); $B_{1}=$ passion fruit peel; $B_{2}=$ purple yam bark; $M=$ methodology; $B=$ biomass.

As for the content of soluble acid lignin, the variation was 11.72 (experiments 1 and 2) and 28.83 (experiments 3 and 4). This means that the interaction effect must be considered, that is, one variable depends on the other. This can be seen in the value of soluble acid lignin in the estimate 4 of the table, which is significant. In the case of pulp, the data indicate that $M_{1}$ was more efficient in extraction and $B_{2}$ contains more pulp, as can be seen in estimates 3 and 4 of table 3 , which correspond to the main effect of biomass and the interaction effect, respectively. The negative sign indicates that the lower level (or class) of the variable is more significant.

Regarding the quantification of sugars and furanic compounds (Table 4), it is observed that when biomass $B_{1}$ is used and the methodology changes from $M_{1}$ to $M_{2}$ (experiments 1 and 2), the glucose concentration increases by $4.83 \mathrm{~g} / \mathrm{L}$. When biomass $B_{2}$ (purple yam bark) is maintained and the methodology changes from $M_{1}$ to $M_{2}$ (experiments 3 and 4), the glucose concentration increases by 8.23 $\mathrm{g} / \mathrm{L}$. This variation indicates that $\mathrm{M}_{2}$ is more efficient in the process of obtaining glucose and that the purple yam bark contains more of this sugar. The estimates also show that the main effect of the methodology is more significant (estimate 2). The same behavior is observed for fructose, but this sugar 
presents itself in low concentration in relation to glucose for both biomasses.

Regarding furanic compounds, the $\mathrm{M}_{2}$ methodology is more efficient in the process of obtaining them; however, furfural demonstrates higher concentrations than hydroxymethylfurfural. As for the biomasses, the variations are not significant.

Table 4: Estimates and effects of variables on the chemical composition of the biomasses.

\begin{tabular}{|c|l|l|l|l|l|l|l|l|}
\hline \multirow{2}{*}{$\begin{array}{c}\text { Components } \\
(\mathrm{g} / \mathrm{L})\end{array}$} & \multicolumn{4}{|c|}{ Experiments } & \multicolumn{4}{c|}{ Estimates } \\
\cline { 2 - 11 } & 1 & 2 & 3 & 4 & 1 & 2 & 3 & M \\
\cline { 2 - 11 } & $\mathrm{M}_{1} \mathrm{~B}_{1}$ & $\mathrm{M}_{2} \mathrm{~B}_{1}$ & $\mathrm{M}_{1} \mathrm{~B}_{2}$ & $\mathrm{M}_{2} \mathrm{~B}_{2}$ & $\mathrm{Mean}$ & $\mathrm{MTD}$ & $\mathrm{BMS}$ & $\mathrm{MTD} / \mathrm{BMS}$ \\
\hline Glucose & 0.61 & 5.44 & 0.70 & 8.93 & 3.92 & 6.53 & 0.79 & 1.70 \\
\hline Fructose & 0.29 & 1.33 & 0.19 & 2.69 & 1.13 & 1.77 & 0.63 & 0.73 \\
\hline Hydroxymethylfurfural & 0.06 & 0.04 & 0.01 & 0.08 & 0.05 & 0.03 & 0.01 & 0.05 \\
\hline Furfural & 0.02 & 1.25 & 0.02 & 0.96 & 0.56 & 1.09 & -0.15 & -0.15 \\
\hline
\end{tabular}

$\mathrm{M}_{1}=\mathrm{NREL} ; \mathrm{M}_{2}=$ Dunning et al. (1949); $\mathrm{B}_{1}=$ passion fruit peel; $\mathrm{B}_{2}=$ purple yam bark; $\mathrm{M}=$ methodology; $\mathrm{B}=$ biomass.

\section{CONCLUSIONS}

The biorefineries present advantages, such as the synthesis and conversion of several biocomposites, the exploitation of the maximum potential of the biomasses, besides adding value to these products, increasing their profitability, and reducing the energy demand and greenhouse gas emissions (NREL, 2008). Therefore, the characterization of the biomass is essential for the evaluation of its use potentials, especially regarding the carbohydrate content.

Under the studied conditions, the hydrolysate obtained from the purple yam bark presented higher sugars concentration (glucose and fructose), according to the methodology of Dunning et al. (1949), and, consequently, higher potential of use as raw material for biorefineries. However, the carbohydrate values obtained are still very low when compared to the amount of pulp and hemicellulose found in both biomasses, which highlights the importance of further studies on the methodologies of degradation of biomass residues, in order to obtain higher carbohydrate concentrations. Therefore, the studies conducted thus far will serve as a basis for the next stages of research.

\section{REFERENCES}

AJAO, O.; MARINOVA, M.; SAVADOGO, O.. Hemicellulose based integrated forest biorefineries: Implementation strategies. Industrial Crops And Products, v.126, n.250, 2018. DOI: https://doi.org/10.1016/j.indcrop.2018.10.025

ALAM, M. D. S.; KHAN, T. S.; HAIDER, M. A.; SAHA, B.. Acid functionalized ionic liquid catalyzed transformation of nonfood biomass into platform chemical and fuel additive. Industrial Crops and Products, v.123, n.629, 2018. DOI https://doi.org/10.1016/j.indcrop.2018.07.036

ASIM, A. M.; UROOS, M.; NAZ, S.; SULTAN, M.; GRIFFIN, G.; MUHAMMAD, N.; KHAN, A. S.. Acidic ionic liquids: Promising and cost-effective solvents for processing of lignocellulosic biomass. Journal of Molecular Liquids, v.287, 2019. DOI: https://doi.org/10.1016/j.molliq.2019.110943

ASTM D 3174-04. Standard method for ash in the analysis sample of coal and coke. West Conshohocken, 2004.

BORGES, M. S.; BARBOSA, R. S.; RAMBO, M. K. D.; RAMBO, M. C. D.; SCAPIN, E.. Evaluation of residual biomass produced in Cerrado Tocantinense as potential raw biomass for bio-refinery. Biomass Conversion \& Biorefinery, v.10,
2020. DOI: https://doi.org/10.1007/s13399-020-00892-x

BRANDT, A.; GRÄSVIK, J.; HALLETT, J. P; WELTON, T.. Deconstruction of lignocellulosic biomass with ionic liquids. Green Chemistry, v.15, n.550, 2013. DOI: https://doi.org/10.1039/C2GC36364J

BROWNING, B. L.. Methods of wood chemistry. Nova York: Wiley \& Sons, 1967

CAI, C.; LIU, Q.; TAN, J.; WANG, T.; ZHANG, Q.; MA, L.. Conversion of cellulose to 5-hydroxymethylfurfural using inorganic acidic catalysts in the presence of pressurized water steam. Bioresources, v.12, 2017 DOI: https://doi.org/10.15376/biores.12.1.1201-1215

CHAU, C. F.; HUANG, Y. L.. Comparison of the Chemical Composition and Physicochemical Properties of Different Fibers Prepared from the Peel of Citrus sinensis. Journal of Agricultural and Food Chemistry, v.51 n.9, p.2615. DOI: https://doi.org/10.1021/jf025919b

DAORATTANACHAI, P.; VIRIYA-EMPIKUL, N.; LAOSIRIPOJANA, N.; FAUNGNAWAKIJ, K.. Effects of Kraft lignin on 
hydrolysis/dehydration of sugars, cellulosic and lignocellulosic biomass under hot compressed water. Bioresource Technology, v.144, n.504, 2013. DOI: http://doi.org/10.1016/j.biortech.2013.06.124

DUNNING, J. W.; DALLAS, D. E.. Analytical Procedures for Control of Saccharification Operations. Analytical Chemistry, v.21, n.727, 1949.

EMBRAPA. Empresa Brasileira de Pesquisa Agropecuária. Maracujá. Brasília: EMBRAPA, 2017.

HIEP, T.; TUAN, B. Q.; PHUONG L. V.; SO'N N. H.; HA, L. V.; TRACH, N. X.. Passion fruit (Passiflora edulis) peel as feed for ruminants in Vietnam: quantification, chemical composition and possibility to make silage. Livestock Research for Rural Development, v.32, n.2, 2020.

LEITE, A. L. M. P.. Obtenção de nanofibras de celulose a partir de subprodutos da mandioca (Manihot esculenta Crantz). Tese (Doutorado em Engenharia de Alimentos) Universidade Estadual de Campinas, Campinas, 2016.

LI, J.; YANG, Y.; ZHANG, D.. DFT study of fructose dehydration to 5-hydrixymethylfurfural catalyzed by imidazolium-based ionic liquid. Chemical Physics Letters, v.723, n.175, 2020. DOI: https://doi.org/10.1016/i.cplett.2019.03.047

MACEDO, L. P. R.; RAMBO, M. K. D.. Biorrefinarias. Caracterização de biomassas residuais do Tocantins por espectroscopia nir aliada a quimiometria visando a obtenção de insumos químicos e condicionadores de solo. Desafios Revista Interdisciplinar da Universidade Federal do Tocantins, v.3, n.49, 2016

NETO, B. B.; SCARMINIO, I. S.; BRUNS, R. E.. Como fazer experimentos: pesquisa e desenvolvimento na ciência e na indústria. 3 ed. Campinas: Unicamp, 2007.

NREL/TP-510-42618. Determination of structural carbohydrates and lignin in biomass. Biomass Analysis Technology Team Laboratory Analytical Procedure. National Renewable Energy Laboratory, 2011.

PEREZ, G. P.; MUKHERJEE, A.; DUMONT, M. J.. Insights into $\mathrm{HMF}$ catalysis. Journal of Industrial and Engineering Chemistry, v.70, n.1, 2019. DOI: https://doi.org/10.1016/j.jiec.2018.10.002

PU, Y.; HU, F.; HUANG, F.; DAVISON, B. H.; RAGAUSKAS, A. J.. Assessing the molecular structure basis for biomass recalcitrance during dilute acid and hydrothermal pretreatments. Biotechnology for Biofuels, v.6, n.15, 2013. DOI: https://doi.org/10.1186/1754-6834-6-15

RAMBO, M. K. D.; ALMEIDA, K. J. C. R.; RAMBO, M. C. D.; BARUQUE FILHO, E. A.. The Response Surface Methodology as a tool to optimize the extraction and acid hydrolysis processes applied to babassu residues. RBPG. Revista
Brasileira de Pós-Graduação, v.13, n.32, 2017. DOI: https://doi.org/10.21713/2358-2332.2016.v13.953

RAMBO, M. K. D.. Silica from Rice Husk Ash as an Additive for Rice Plant. Journal Of Agronomy, v.10, p.99-104, 2011. DOI: https://doi.org/10.3923/ia.2011.99.104

RAMBO, M. K. D.; SCHMIDT, F. L.; FERREIRA, M. M. C.. Analysis of the lignocellulosic components of biomass residues for biorefinery opportunities. Talanta, v.144, p.696703, 2015. DOI:

https://doi.org/10.1016/j.talanta.2015.06.045

ROCHA, G. J. M.; NASCIMENTO, V. M.; GONÇALVES, A. R.; SILVA, V. F. N.; MARTÍN, C.. Influence of mixed sugarcane bagasse samples evaluated by elemental and physicalchemical composition. Industrial Crops and Products, v.64, n.52, 2015. DOI: https://doi.org/10.1016/j.indcrop.2014.11.003

SILVA, C. E. D. F.. Pré-tratamento alcalino de resíduo de maracujá visando à obtenção de etanol. 2015.

SINGH, Y. D.; MAHANTA, P.; BORA, U.. Comprehensive characterization of lignocellulosic biomass through proximate, ultimate and compositional analysis for bioenergy production. Renewable Energy, v.103, n.490, 2017. DOI: https://doi.org/10.1016/j.renene.2016.11.039

SIQUEIRA, G.; BRAS, J.; DUFRESNE, A.. Luffa cylindrica as a lignocellulosic source of fiber, microfibrillated cellulose and cellulose nanocrystals. Bio Resources, v.5, n.727, 2010.

TIBOLLA, H.; PELISSARI, F. M.; MENEGALLI, F. C.. Cellulose nanofibers produced from banana peel by chemical and enzymatic treatment. LWT - Food Science and Technology, v.59, 2014. DOI: https://doi.org/10.1016/j.lwt.2014.04.011

TRUJILLO, A. I.; MARICHAL, M. D. J.; CARRIQUIRY, M. Comparison of dry matter and neutral detergent fibre degradation of fibrous feedstuffs as determined with in situ and in vitro gravimetric procedures. Animal Feed Science and Technology, v.161, p.49-57, 2010. DOI: https://doi.org/10.1016/i.anifeedsci.2010.08.001

VAZ JUNIOR, S.. Rumo a uma Química Renovável Brasileira a partir da Biomassa Vegetal. Revista Virtual de Química, v.9, n.238, 2017.

VERSINO, F.; LÓPEZ, O. V.; GARCÍA, M. A.. Sustainable use of cassava (Manihot esculenta) roots as raw material for biocomposites development. Industrial Crops and Products, v.65, p.79-89, 2017. DOI: https://doi.org/10.1016/j.indcrop.2014.11.054

ZHAO, X.; LIU, D.. Chemical and thermal characteristics of lignins isolated from Siam weed stem by acetic acid and formic acid delignification. Industrial Crops and Products, v.32, p.284-291, 2010. DOI: https://doi.org/10.1016/j.indcrop.2010.05.003

A CBPC - Companhia Brasileira de Produção Científica (CNPJ: 11.221.422/0001-03) detém os direitos materiais desta publicação. Os direitos referem-se à publicação do trabalho em qualquer parte do mundo, incluindo os direitos às renovações, expansões e disseminações da contribuiç̃o, bem como outros direitos subsidiários. Todos os trabalhos publicados eletronicamente poderão posteriormente ser publicados em coletâneas impressas sob coordenação da Sustenere Publishing da Companhia Brasileira de Produção Científica e seus parceiros autorizados. Os (as) autores (as) preservam os direitos autorais, mas não têm permissão para a publicação da contribuição em outro meio, impresso ou digital, em português ou em tradução. 